\title{
ENSINO-APRENDIZAGEM-TREINAMENTO DOS SISTEMAS OFENSIVOS E DEFENSIVOS DO HANDEBOL NA OPINIÃO DE TREINADORES DA CATEGORIA CADETE.
}

\section{Fernando da Silva Pereira*; Heloisa Helena Baldy dos Reis}

\begin{abstract}
Resumo
Os jogos coletivos esportivizados (JCEs) apresentam em seu conteúdo princípios operacionais interligados para o seu desenvolvimento. Para o seu ensino, é necessário que os treinadores utilizem metodologias de ensino-aprendizagemtreinamento (EAT) para que seus atletas respondam de maneira eficaz as situações imprevisíveis pelo ambiente do jogo. Este trabalho pretendeu verificar a metodologia escolhida pelos treinadores para o ensino dos sistemas defensivos e ofensivos do handebol na categoria cadete, por meio de pesquisa qualitativa pelo método do discurso do sujeito coletivo (DSC) para obter informações sobre atitudes, métodos e comportamento humano perante situações do jogo.
\end{abstract}

\section{Palavras-chave:}

Ensino-aprendizagem-treinamento; Handebol; Cadete

\section{Introdução}

Nos JCEs estão presentes, segundo Bayer (1994): aspectos táticos, técnicos e psicológicos, relacionados diretamente com as situações imprevisíveis do jogo, desta forma os JCEs se tornam objeto de estudo de várias perpectivas e por diversas àreas do conhecimento. Nos JCEs, são encontrados principios operacionais referentes ao ataque e defesa, sendo necessário então que os jogadores se utilizem de sistemas ofensivos (SO) e sistemas defensivos (SD) para que se obtenha o êxito em determinadas situações. Wright et al (2004), estabeleceram que 0 treinador tem uma total importância, pois seus conhecimentos e competências são fundamentais para que equipes desenvolvam bem os JCEs. Desta forma o objetivo desta pesquisa foi ouvir os treinadores, tendo em vista que a concepção táticaestratégica de uma equipe não depende apenas dos jogadores, mas também da metodologia de EAT escolhida pelos técnicos para um bom desenvolvimento e aprendizado dos SO e SD do handebol na categoria cadete.

\section{Metodologia}

A amostra foi constituída por dois treinadores de clubes com tradição no handebol e com atuação em ao menos um campeonato na categoria cadete feminina e/ou masculina. Todos os treinadores são graduados em Educação Física e com pós-graduação em áreas correlatas do handebol. Por meio de entrevista semiestruturada mediante gravações, tivemos a aprovação pelo Comitê de Ética em Pesquisa Institucional. Para organização, tabulação e interpretação dos dados qualitativos de natureza verbal, obtidos a partir de entrevistas, foi utilizado o método do Discurso do Sujeito Coletivo (DSC).

\section{Resultados e Discussão}

Com base nas transcrições dos discursos dos treinadores e da tabulação dos dados a partir do DSC, foi possível observar que ambos os treinadores salientam que a categoria cadete apresenta-se como um momento importante na formação do atleta, ao qual os jogadores precisam ter um dominio maior do conhecimento tático do jogo. A utilização de métodos ativos para o ensino dos JEC, como é o caso do método global-funcional (que prioriza o ensino por meio de jogos) e do método situacional (que prioriza o ensino a partir de unidades funcionais menores extraídas do próprio jogo), vem ganhando cada vez mais espaço a partir das entrevistas. Ainda considerando esse contexto é desejável que, durante as etapas iniciais do processo de EAT (categorias mirim, infantil e cadete), se estabeleçam as bases para maiores rendimentos no futuro, assim é identificadobuma procura no desenvolvimento dessas bases para o desenvolvimento futuro. Tais posicionamentos contrapõem a ideia de especialização esportiva precoce a partir da diversificação das práticas em treinamento. Ambos concordam que para o cenário técnico-tático dos SO e SD apontam para diferentes possibilidades de eficácia relacionada com a execução dos fundamentos ou a manifestação de determinados meios técnico-táticos (MTT) individuais e coletivos no jogo.

\section{Conclusões}

A partir do DSC foi possível identificar a preocupação com a formação dos jogadores em longo prazo quando o assunto envolve os SO e SD. Destaca-se, também, a priorização pelo ensino por meio de jogos e ambientes complexos e imprevisíveis, contemplando princípios comuns ao jogo formal de handebol. O DSC também aponta que é importante que o ensino e inserção dos MTT coletivos e individuais nos treinamentos sejam apresentados de forma cautelosa e prioriozando a identificação e leitura do jogo para a tomada de decisão correta dentro dos SO e SD.

\section{Agradecimentos}

Ao PIBIC/Cnpq pelo suporte e bolsa e ao treinadores pela participação na pesquisa.

BAYER, C. O ensino dos desportos colectivos. Lisboa: Dinalivros, 1994.

WRIGHT, T.; TRUDEL, P.; CULVER, D. Learning how to coach: the different learning situations reported by youth ice hockey coaches. Phys Educ Sport Pedagog 2007;12(2):127-44 